\title{
Corporate Governance Principles Introduced by the Capital Markets Board of Turkey and an Investigation About Internal Audit in Companies Listed on Borsa Istanbul
}

\begin{abstract}
Ahmet Tanç
Nevşehir Hacı Bektaş Veli University, Nevşehir, Turkey

Today's global trends need to be clearly explained to enable the efficient functioning of capital markets for the purpose of the country's economic development. Promotion of a strong internal audit function plays a key role in assisting the board to discharge its governance responsibilities. The internal audit needs to exert its important function for refining corporate governance procedures, improving internal control, and strengthening risk management. The rules concerning internal auditing issued by the Banking Regulation and Supervision Agency, Capital Markets Board of Turkey, and other public societies have contributed to the development of internal auditing in Turkey. The Capital Markets Board of Turkey published "Communiqué Serial: IV, No: 56 on Identification and Application of Corporate Governance Principles" (Official Gazette dated December 30, 2011, No. 28158). In Part 4.2.4 of these principles, it was stated that "The board of directors supervise the efficiency of risk management and internal control systems at least once a year. Information about existence, operation, and efficiency of internal control and internal audit is given by annual report". The objective of this study is to analyze the structure of internal audit function-related information on the annual reports of companies that are included in the Borsa Istanbul. Annual reports of 192 manufacturing companies listed on Borsa Istanbul were examined by content analysis method.
\end{abstract}

Keywords: internal auditing, corporate governance, Borsa Istanbul

\section{Introduction}

Through the financial scandals and globalization, corporate governance, reliable information, and reliable information-based professions have become increasingly important. Establishing an effective internal audit department in an organization as an integral part of a strong internal control system is one of the main elements of corporate governance. Internal auditing has been considered as a profession on the global scale since the early 1940s and recently, there has been an ongoing interest in jobs in developed and developing countries including Turkey. Good corporate governance mechanisms and practices lead to favorable outcomes for companies and countries. Thanks to the high level of corporate governance practices, companies can face lower cost of capital, increase financial capabilities and liquidity, overcome crises more easily, and can be recognized for soundly-managed companies in the capital markets.

\footnotetext{
Ahmet Tanç, assistant professor, Faculty of Economics and Administrative Sciences, Nevşehir Hacı Bektaş Veli University. Email: atanc@nevsehir.edu.tr.
} 
Internal audit is one of the modern business functions and the information provided by this function has a great value for the management of the entity. In many cases, managers base their decisions on findings and recommendations from the internal audit reports (Susmanschi \& Georgescu, 2014). Globalization will result in new challenges for internal auditing because of the ease of offshoring of both manufacturing and administrative processes, frequency of joint ventures, and other changes. Recognition of varying international standards, political risks, and the need for cultural sensitivity are becoming increasingly important. Factors that are driving increases in internal audit responsibilities include (PwC, 2007):

(1) Continuous auditing or monitoring;

(2) Auditing the enterprise risk management (ERM) process;

(3) Auditing outsourced or offshored operations;

(4) Fraud detection;

(5) Fraud risk assessment;

(6) Auditing executive compensation and disclosures;

(7) Auditing operational efficiency and effectiveness.

The Capital Markets Board of Turkey has recently reformed major aspects of the Corporate Governance Principles for companies listed on Borsa Istanbul which were, prior to the reform, based on a "comply or explain" approach. The changes were notified with two communiqués (Series: IV, No. 56 and No. 57) on December 30, 2011 and February 11, 2012 (Ararat \& Yurtoğlu, 2012). The Board's Communiqué on Identification and Application of Corporate Governance Principles (Serial: IV, No. 56) and Communiqué on Emendation of Communiqué on Identification and Application of Corporate Governance Principles (Serial: IV, No. 57) are hereby repealed and superseded. Instead of these communiqués, the Capital Markets Board of Turkey published "Serial: II, No. 17.1-Communiqué on Corporate Governance" (Official Gazette dated January 3, 2014, No. 28871). Some articles of Corporate Governance Principles were made compulsory by the Capital Markets Board of Turkey with Serial: IV, No. 56 and Serial: II, No. 17.1. In Part 4.2.4 of these principles, it was stated that "The board of directors supervise the efficiency of risk management and internal control systems at least once a year. Information about existence, operation, and efficiency of internal control and internal audit is given by annual report". Part 4.2.4 of these principles is not compulsory. On the other hand, in Article 6 of communiqués (Serial: IV, No. 56 and Serial: II, No. 17.1), it was stated that, "In the annual reports, listed companies make a statement whether or not Corporate Governance Principles are applied; if a principle is not applied, the corresponding place will give a reasoned explanation".

The principles consist of four main sections, namely, shareholders, disclosure and transparency, stakeholders, and board of directors (Capital Markets Board of Turkey, 2003). These principles are stated by the Capital Markets Board of Turkey in the following:

(1) The first section discusses the principles on shareholders' rights and their equal treatment. Issues such as shareholders' right to obtain and evaluate information, right to participate in the general shareholders' meeting, right to vote, right to obtain dividend, and minority rights are included in detail in this section. Matters such as keeping records of shareholders and the free transfer and sales of shares are also discussed hereunder;

(2) The second section discusses the principles regarding disclosure and transparency issues. Within this scope, principles for establishment of information policies in companies with respect to shareholders and the adherence of companies to these policies are discussed. The conditions of today's global financial economy and conditions faced in our country have been taken into consideration while setting single standards for the 
procedures of providing information via periodic financial statements and reports and detailing such standards through consideration of functionality;

(3) The third section is concerned mainly with stakeholders. A stakeholder is defined as an individual, institution, or an interest group that is related with the objectives and operations of a company in any way. Stakeholders of a company include the company's shareholders and its workers, creditors, customers, suppliers, unions, various non-governmental organizations, and the government and potential investors who may consider investing in the company. This section includes the principles to regulate the relationship between the company and stakeholders;

(4) The fourth section includes principles concerning functions, duties, obligations, operations, and structure of the board of directors; remuneration thereof, as well as the committees to be established to support the board operations and the executives.

The aim of this study is to analyze the given information about internal audit function on the annual reports of companies that are included on Borsa Istanbul. Annual reports of 192 manufacturing companies listed on Borsa Istanbul were examined by content analysis method. Through this analysis, it will be possible to evaluate the development of internal audit in terms of corporate governance in Turkey. This paper evaluates the outcomes of the Capital Markets Board of Turkey's Communiqués on Corporate Governance from an internal auditing perspective.

\section{Corporate Governance and Internal Auditing}

Internal auditing includes a wide range of activities, such as financial statement auditing, compliance auditing, operational auditing, and information technology auditing. Internal auditing is accepted as an indispensable function for the reliability of financial reporting, compliance of acts and regulations, efficiency of operations, and information system safety. Organizations need to have an internal auditing department for the reasons as follows (Selimoğlu, 2010):

(1) Internal auditing contributes to the settlement of managerial accountability thought in companies;

(2) As a part of risk management, it plays a preventative role;

(3) Internal auditing forwards the quality of corporate governance;

(4) It increases the organizational value;

(5) It provides assurance for shareholders and stakeholders.

Corporate governance is a system in which firms are managed and controlled by accountability, fairness, and transparency. Healthy growth of businesses and conservation of continuity depend on adaptation of corporate governance principles (Uzay, 2010). Although not yet common, an emerging request from boards is that internal auditors review and comment on the organization's governance policies, processes, and practices (Marks, 2007). The Institute of Internal Auditors (IIA) accepts this in its International Standards for the Professional Practice of Internal Auditing. Standard 2100 (Nature of Work) states that, "The internal audit activity must evaluate and contribute to the improvement of governance, risk management, and control processes using a systematic and disciplined approach". Adding to this, Standard 2110 (Governance) signifies:

The internal audit activity must assess and make appropriate recommendations for improving the governance process in its accomplishment of the following objectives: (1) promoting appropriate ethics and values within the organization; (2) ensuring effective organizational performance management and accountability; (3) communicating risk and control information to appropriate areas of the organization; and (4) coordinating the activities of and communicating information among the board, external and internal auditors, and management. (IIA, 2012, p. 11) 


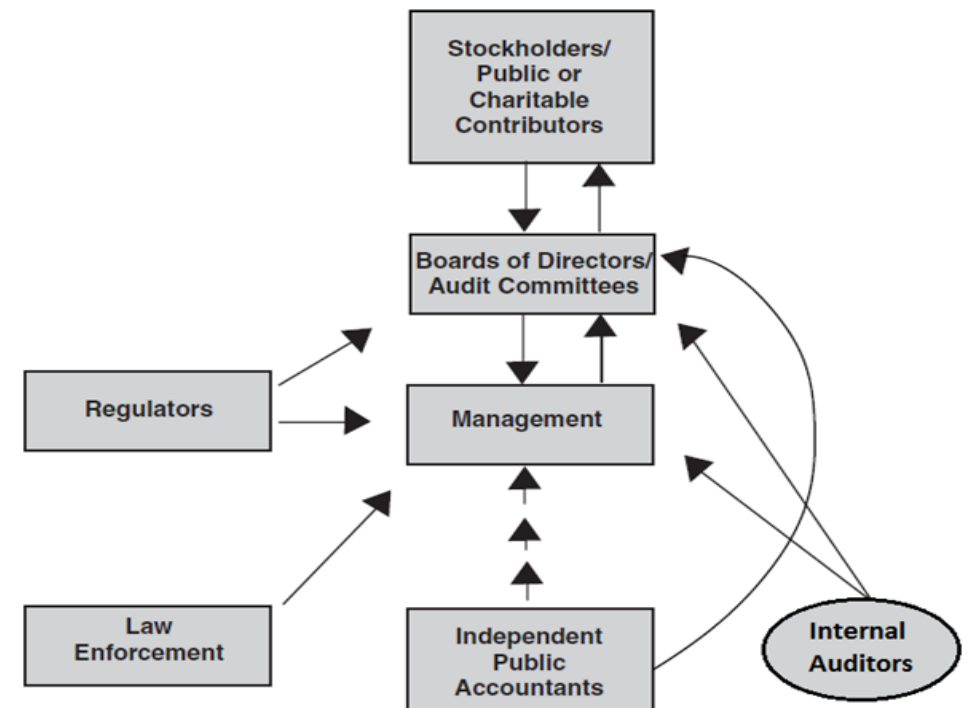

Figure 1. Parties involved in organizational governance. Source: Hermanson and Rittenberg (2003).

Various bodies participate in firm-level governance from management and the board to the internal and external auditors, as shown in Figure 1. In some cases, regulatory authorities or professional associations also contribute to the governance process. Management often appeals to internal auditors to provide their assurance with the following: (1) Potential risks are effectively assessed and managed; (2) Organizational processes are effectively controlled; and (3) Organizational processes are efficient or effective. In this structure, the internal audit function plays a unique role (Hermanson \& Rittenberg, 2003). Internal auditors, by having an objective view from inside the organization, can play a vital role in the governance process by keeping management and the board conscious of control and risk matters and by assessing the effectiveness of risk management and management's control practices. Given the current business environment, it is surprising that boards of directors or management would prefer to act without internal auditing. All organizations should have a fully resourced, independent internal audit department that is professionally staffed and chartered to evaluate the risk management, control, and governance process (Tarr, 2003).

The audit committee's demand for better internal controls may lead to a greater focus on internal controls and increase interactions between audit committees and internal audit functions. Interactions between the audit committee and the internal audit function are important for the audit committee in fulfilling its oversight role. Concerns about corporate governance and auditing have prompted regulators to initiate measures aimed at restoring trust and legitimacy, and corporate governance codes in many countries now place a significant emphasis on the oversight of the internal audit process by the audit committee. Audit committees are experiencing an ever-expanding monitoring role as corporate governance regulations and guidelines place a greater emphasis on strengthening the relationship between the internal audit function and the audit committee, via formal as well as informal meetings (Zaman \& Sarens, 2013).

In the portion of this paper so far, we have tried to give some information about the relationship between internal auditing and corporate governance, and the role of internal audit in a strong corporate governance structure. In the following section of this paper, we will analyze the structure of internal audit function-related information on the annual reports of companies that are included on Borsa Istanbul. Annual reports of 192 manufacturing companies listed on Borsa Istanbul were examined by content analysis method. 


\section{Investigation About Internal Audit in the Annual Reports of Companies Listed on Borsa Istanbul}

Global expansion, rising costs, supply chain disruptions, economic crises, and increasing customer demand for product and service differentiation rank are key issues for many manufacturers. Most of these factors bring both new pressures and opportunities for internal audit functions. Executive teams and their boards want to understand how certain risks, such as the financial viability of suppliers and/or customers during the credit crunch, caught their organizations off guard. All of these pressures influence internal audit functions in the manufacturing industry. Internal auditors are expected to address new and familiar risks and opportunities in a more efficient manner (Protiviti, 2012).

In this paper, the method of content analysis was employed for examining the effects of the Corporate Governance Principles introduced by the Capital Markets Board of Turkey on explications regarding internal auditing. According to data from the Public Disclosure Platform (PDP) ${ }^{1}$, there are 192 manufacturing companies listed on Borsa Istanbul. Annual reports of 192 companies, for the year ended December 31, 2012, were obtained from the PDP and companies that own websites. We obtained annual reports, because Corporate Governance Principles Compliance Report is a part of company annual reports.

Table 1

Existence of Corporate Governance Principles Report and Explanation for Internal Auditing

\begin{tabular}{lrll}
\hline Dimension of investigation & Yes & No & Total $(n)$ \\
\hline Existence of Corporate Governance Principles Compliance Report on Annual Report & 164 & 28 & 192 \\
Explanation for internal auditing & 81 & 83 & 164 \\
\hline
\end{tabular}

According to Table 1, 164 of 192 manufacturing companies have Corporate Governance Principles Compliance Report on Annual Report and the remaining 28 companies do not have Corporate Governance Principles Compliance Report. In addition, 81 manufacturing companies have included a statement on internal auditing in Corporate Governance Principles Compliance Report, while the remaining 83 companies made no explanation for internal auditing in their corporate governance principles compliance reports. This is a quite negative indicator for good corporate governance.

In Part 4.2.4 of the Capital Markets Board of Turkey's Corporate Governance Principles, it was stated that, "The board of directors supervise the efficiency of risk management and internal control systems at least once a year. Information about existence, operation, and efficiency of internal control and internal audit is given by annual report". The existence, operation, and efficiency are most widely used dimensions for collecting information about internal control and internal auditing in an organization.

Table 2

Scope of Information About Internal Auditing in Corporate Governance Principles Compliance Report of 81 Manufacturing Companies

\begin{tabular}{lll}
\hline Scope of information & $f$ & $\%$ \\
\hline Only existence & 27 & 33.3 \\
Existence and operation & 31 & 38.3 \\
Existence, operation, and efficiency & 23 & 28.4 \\
Total & 81 & 100 \\
\hline
\end{tabular}

\footnotetext{
${ }^{1} \mathrm{PDP}$ is an electronic system through which electronically signed notifications required by the capital markets and Borsa Istanbul regulations are publicly disclosed (retrieved from http://www.kap.gov.tr/).
} 
As seen from Table 2, 27 (33.3\%) of the 81 manufacturing companies have made a statement only about the existence of a separate internal audit department in their corporate governance principles compliance reports. On the other hand, in their corporate governance principles compliance reports, 12 of these 27 manufacturing companies have explained that they have not got internal auditing functions in companies. Some sample statements on internal auditing in Corporate Governance Principles Compliance Report of 12 manufacturing companies are given below:

(1) Efforts continue to establish an internal audit department in our company (Altınyıldız Textile);

(2) In our company, an audit committee has been formed and we also have started to work for setting up an internal audit department (İhlas Gazetecilik);

(3) We do not have an internal audit department to control all the processes in our company. But firm management controls sufficiently. In our company, a necessary assignment of duties is made and is not allowed to unauthorized transactions (Sodaş Sodyum Sanayii);

(4) The board has not established a risk management and internal audit department to minimize the impacts of risks that affect the stakeholders (Akın Textile).

The structure and reporting lines adopted for the internal audit function should reinforce independence, objectivity, consistency, and business understanding. This aim can be achieved by combining the concept of a clear reporting line to the board/audit committee with an organizational structure that allows internal audit to operate independently of other functions within the organization (KPMG, 2003). Effective corporate governance is a synergy among internal auditors, the board of directors, senior management, and external auditors (Cangemi \& Singleton, 2003).

According to our content analyses, 31 (38.3\%) of the 81 manufacturing companies have made a statement about the existence and operation of an internal audit department in their corporate governance principles compliance reports. Additionally, 23 (28.4\%) of the 81 manufacturing companies have made a statement about the existence, operation, and efficiency of an internal audit department in their corporate governance principles compliance reports.

Some good samples of 54 manufacturing companies that have included a statement (existence and operation or existence, operation, and efficiency) on internal auditing in Corporate Governance Principles Compliance Report are given below:

(1) Coca-Cola İçecek's (CCI) internal audit department evaluates risks in terms of the company's goals and the internal control system that is in place to manage those risks. Management shares action plans needed to further mitigate those risks with internal audit executive to report to the audit committee. CCI's internal audit department, based on the results of the risk assessment, evaluates the company's risk management and internal control system on a regular basis and reports to the audit committee as well as company management to ensure:

(a) Accuracy and reliability of financial and operational information;

(b) Effectiveness and efficiency of operations;

(c) Safeguarding of company assets;

(d) Compliance with laws, regulations, and contracts.

(2) The main function of the internal audit department is to provide Çimsa Çimento San. ve Tic. A.Ş. with independent, objective assurance and consultancy services by using international internal audit standards. Internal audit department, operating under the audit committee consisting of members of the board of directors, 
conducts audits, interrogations, and examinations to protect the company's rights and interests and develop recommendations for the internal and external risks of the company;

(3) Petkim's (Petrokimya Holding A.Ş.) internal audit unit conducts auditing and reports the results within the framework of annual internal audit plan. Carrying out its business with a risk-focused and proactive approach, the unit particularly focuses on the most risky fields, shares the results with related departments, ensures that required action plans are made, and follows up the improvements. The internal audit unit classifies its activities under four groups: compliance, operations, financial tables, and specific audits;

(4) Ford Otosan's audit committee periodically monitors internal control and internal audit activities as a sub-committee of board of directors. It submits the financial reports conformity and recommendations to the board of directors. Koç Holding, Ford Motor Company, and internal audit make investigations within the company on an annual basis. Stakeholders can report practices which violate regulations and ethically inappropriate transactions to the internal audit department to be communicated to the audit committee;

(5) In Trakya Cam Sanayii A.Ş., risk management and internal auditing are carried out under the coordination of the "risk management" department of the holding company. Internal auditing and risk management functions communicate with each other at the highest level, and risk-focused internal auditing efforts aim to increase corporate governance.

Some poor samples of 54 manufacturing companies that have included a statement (existence and operation or existence, operation, and efficiency) on internal auditing in Corporate Governance Principles Compliance Report are given below:

(1) In Arçelik A.Ş., an internal audit department was established within the vice president of finance and financial affairs;

(2) In Çemtaş, internal audit has been realized by the audit committee at least four times per year;

(3) In DesaDeri, risk management embracing financial risk, market risk, and operational risk is made by the finance department periodically. And also, financial affairs department and internal audit committee are responsible for company internal control systems;

(4) In Kristal Cola and Mutlu Akü, to set up a strong internal control, we have been trying to set up a strong internal control within the vice president of finance and financial affairs;

(5) In Sarkuysan Elektrolitik Bakır Sanayi ve Ticaret A.Ş., the internal audit system of the company consists of job descriptions, authorization system, policies, and written procedures which were determined according to the work flow and processes. With the internal auditing, the company aims to accomplish its objectives in terms of efficiency and effectiveness of operations, the reliability of financial reporting, and compliance with laws and regulations. Internal audit system regularly passes through a periodic evaluation process, and effectiveness of the production operations is audited by the quality assurance department.

Examples above can be increased by the content analysis on annual reports in this paper.

\section{Summary and Conclusions}

Internal auditors in a changing business environment have become a strategic initiative for management, the audit committee, the board of directors, the external auditors, and other key stakeholders. When appropriately designed and operated, the internal audit function can meet management's expectations and play an important role in promoting and supporting effective organizational governance. 
Organizational governance consists of interrelated components consisting of board of directors and committees, legal and regulatory environment, disclosure and transparency, business practices and ethics, ERM, and monitoring and communication.

Internal audit performs a very critical role in organizational governance by understanding and evaluating these components and providing value-added support for their improvement. A holistic view of organizational governance provides an internal audit opportunity to play a more active and strategic role. Internal audit can maximize its contribution to good governance by having a direct functional reporting line to the audit committee and exhibiting high quality of professionalism and quality in its work. The ultimate purpose of internal audit is to improve organizational performance (Institute of Chartered Accountants of India [ICAI], 2014).

In essence, the importance of internal auditing as a unit of service is generally accepted with an increasing speed in Turkey. Some findings and thoughts on improvement of internal auditing in Turkey are as follows:

(1) We must find a solution to the question: "In what ways can an efficient and productive internal audit department be established?". The most appropriate and valid method shall be the implementation of standards issued by the IIA. Since external and internal audits are generally perceived as a burden by the enterprise owners in Turkey, they do not consider the quality and efficiency of audit, thus they perform the audits only for show and under compulsion. First of all, this misconception, which is thoroughly wrong, must be rectified in order to promote both external and internal auditing in Turkey;

(2) We cannot compliment on an internal audit function let alone an internal audit in compliance with international standards for a company, which has in no way established a governance culture in the real sector;

(3) Some firms believe that internal auditors are responsible for establishing internal controls. In fact, boards are responsible for establishing and maintaining adequate and effective internal control. But internal audit is responsible for an objective evaluation of the existing risk and internal control framework;

(4) According to the annual reports, some companies think that audit committees are responsible for maintaining the internal audit activities. The truth is that the audit committee should take all necessary measures in order to ensure that internal and external auditing is carried out adequately and transparently.

Annual reports are the most valuable communication channels between management team and other stakeholders. Ultimately, its purpose is to convey an organization's unique position and build confidence among its key stakeholders. In accordance with this, companies need to pay more attention to preparing their annual reports. And also, companies' annual reports should include more detailed information about internal audit functions.

\section{References}

Ararat, M., \& Yurtoğlu, B. B. (2012). An assessment of the recent legal reforms concerning "corporate governance" introduced by the Capital Market Boards of Turkey. Sabanc1 University Corporate Governance Forum of Turkey, CGFT Working Papers. Retrieved from http://ssrn.com/abstract=2040376

Cangemi, M. P., \& Singleton, T. (2003). Managing the audit function: A corporate audit department procedures guide (3rd ed.). Hoboken: John Wiley \& Sons.

Capital Markets Board of Turkey. (2003). Corporate governance principles. Retrieved from http://www.cmb.gov.tr/regulations/files/corporate_governance.pdf

Hermanson, D. R., \& Rittenberg, L. E. (2003). Internal audit and organizational governance. In A. D. Bailey, A. A. Gramling, \& S. Ramamoorti (Eds.), Research opportunities in internal auditing (pp. 25-71). USA: The Institute of Internal Auditors.

Institute of Chartered Accountants of India [ICAI]. (2014). Knowledge booklet series I: "Enhancing governance through internal audit”. New Delhi, India. Retrieved from http://www.icai.org/ 
Institute of Internal Auditors [IIA]. (2012). International standards for the professional practice of internal auditing (standards). Altamonte Springs, FL. Retrieved from http://www.theiia.org/guidance/standards-and-guidance/ippf/standards/full-standards/ KPMG. (2003). Internal audit's role in modern corporate governance (pp. 1-9). Hong Kong.

Marks, N. (2007). Internal audits of governance (pp. 31-33). The Internal Auditor, ABN/INFORM Global.

PwC. (2007). Internal audit 2012: A study examining the future of internal auditing and the potential decline of a controls-centric approach. Retrieved from http://www.pwc.com/us/en/internal-audit/assets/pwc_ias_2012.pdf

Protiviti. (2012). Top priorities for internal audit in manufacturing: Assessing manufacturing industry results from the 2012 internal audit capabilities and needs survey. Protiviti. Risk \& Business Consulting. Retrieved from http://www.protiviti.com/en-US/Documents/POV/2012-Internal-Audit-Survey-Manufacturing-Industry-Protiviti.pdf

Selimoğlu, K. S. (2010). İç Denetim Eğitiminin Gelişimi ve Geleceği: Uluslararası ve Ulusal Boyut. Paper presented at the Akademik Forum (pp. 57-79), Türkiyeİç Denetim Enstitüsü Yayınları, Yayın No. 2.

Susmanschi, G., \& Georgescu, L. S. (2014). Performance evaluation of internal audit. Economics, Management, and Financial Markets, 9(1), 485-491.

Tarr, R. H. (2003). Establishing an internal audit activity manual. Florida: The Institute of Internal Auditor.

Uzay, S. (2010). Reel Sektörde İ̧̧ Denetim Uygulamaları: Tespit ve Öneriler. Türk Sanayicileri ve İşadamları Derneği, Yayın No. TÜSİAD-T/2010-05/501.

Zaman, M., \& Sarens, G. (2013). Informal interactions between audit committees and internal audit functions: Exploratory evidence and directions for future research. Managerial Auditing Journal, 28(6), 495-515. 